\title{
Ethnic Identity of Kazakhstani Russians: The Dynamics of Change and the Place of Russia as a Kin State
}

\author{
Mukhtar Senggirbay \\ Suleyman Demirel University
}

\begin{abstract}
The aim of this paper was to find out how the ethnic identity of Russians residing in Kazakhstan has changed since the collapse of the Soviet Union in 1991. What qualities and characteristics distinguish ethnic Russians in Kazakhstan now? What are the main factors shaping their identity? To what extent Russians see aligned with their homeland and with the mainstream Kazakh society. What is the role of Russia in promoting a sense of attachment to the homeland? The case of Kazakhstani Russians was analyzed applying the various methods of qualitative research, including surveys, in-depth interviews, content analysis of the publications, and the speeches of political figures and activists. In addition, the methods of participant observation helped in understanding the cultural differentiation of the Russian religious organizations in Kazakhstan. The research revealed the significant changes in the identity patterns of ethnic Russians in Kazakhstan, which resulted from the process of consolidation of the vigorous state-protected ethnic Kazakh identity. Losing the previous dominant position in demography, the Russians bowed to the inevitable Kazakhification of the society. The change in the language preferences shows that the new generation of Russians is gradually accepting the new trend - Kazakh-Russian bilingualism - which is being promoted and implemented by the government of Kazakhstan and by the overwhelmingly ethnocratic Kazakh political elite.
\end{abstract}

\section{Keywords}

ethnic identity; Kazakhstani Russians; Kazakhstan; nation building; Kazakhification; Kazakh-Russian bilingualism

\section{Introduction}

The issue of ethnic Russians residing in Kazakhstan was rarely considered as a complexity of factors, which may include a) the nationalizing state policy of Kazakhstan and the more ethnocratic government; b) the mobilizing force of the Kazakh ethnic consciousness, which is influenced by the postcolonial hostility toward Russia and the Soviet legacy; c) the disorientation of Russian

\footnotetext{
* Mukhtar Senggirbay, Suleyman Demirel University, 1/1 Abylaikhan Sreet, Kaskelen, Almaty Region, Kazakhstan,040900; mukhtar.senggirbay@sdu.edu.kz.
} 
population predominantly residing in the northern part of Kazakhstan, who barely recognize the validity of the Kazakhstani statehood in the territory, where they have been living two to three centuries; and d) the foreign policy of the Russian Federation, which is becoming more and more aggressive in protecting the rights of Russian "compatriots" living in the former Soviet republics. The empirical research to date examines the issue of Russian ethnic identity in Kazakhstan in broad or correlated contexts. Most authors analyze the topic from the prism of a big "Russian World", considering Russianspeaking population of Kazakhstan as the part of this vast community. ${ }^{1}$ Some looked at it together with the problems of the Russian diaspora in the former Soviet Union.

The aim of this paper was to find out how the ethnic identity of Russians residing in Kazakhstan has changed since the collapse of the Soviet Union in 1991. What qualities and characteristics distinguish ethnic Russians in Kazakhstan? What are the main factors shaping their identity? To what extent Russians see aligned with their homeland and with the mainstream Kazakh society. What is the role of Russia in promoting a sense of attachment to the homeland?

The previous works that examined the national construction practices in Kazakhstan have a gap that needs to be filled: they primarily focus on the behavior of the central governments, mostly describing the ethnic identity construction as a top-down process. This especially concerns the Western authors, who paid a particular attention to the issues of national identity in Kazakhstan. Martha Brill Ollcott (2002) first noticed the significant nationalizing policy of the new government of Kazakhstan, while Peyrouse (2007) elaborated on the passiveness of ethnic Russians in pursuing its own ethnic agenda. The works of Schatz (2000), Oka (2007), Esenova (2002), Laruelle and Peyrouse (2007), and others contributed to the research of identity construction in Kazakhstan from various angles, though lacking the complex analysis of the factors, dimensions, and the dynamics of the shift in the identity of ethnic Russians in Kazakhstan.

Almost all the recent works on nation-building processes in Kazakhstan underline the role of the pro-Kazakh ethnocratic government as the main factor shaping the national identity construction processes. Laruelle (2015) pointed out the role of the television and the media mostly controlled by the autocratic government in strengthening the Kazakh cultural identity. Other scholars, such as Isaacs and Polese (2015) concluded that the government of

1 See, for example, Laruelle (2007). 


\section{Mukhtar Senggirbay \\ Ethnic Identity of Kazakhstani Russians}

Nazarbayev was creating an "imagined" Kazakh nationhood with the help of the official historiography.

However, most of the data on which the scholars based their conclusions are outdated. As Kazakhstan and the whole region experienced tremendous ethnodemographic changes in the recent decade, the data used by these authors are no longer relevant. Around four million ethnic Russians, as well as Germans, Ukrainians, Greeks, and others, left Kazakhstan in the past decade. Moreover, the geopolitical situation in the region has been changed substantially. The Russian Federation, the historical homeland of four million Russians living in Kazakhstan, is drifting to a more belligerent foreign policy, especially with respect to the neighboring countries. Thus, this paper is intended to scrutinize the current condition of ethnic relations in Kazakhstan in order to fill the gap in the analysis of the dynamics of and the factors for the ethnic and national identity solidification processes going on in this multicultural nation located in Central Asia. The contribution of this research to the empirical study of the topic would be the elaborated analysis of the ethnic repertoire of Russians, as well as their current attitude to the foreign policy of Moscow and to the nationalizing domestic policy of Kazakhstan. In general, this paper will try to prove that Kazakhstan is experiencing the process of constructing a unique ethno-cultural group of "Kazakhstani Russians", which has never been a topic of serious scientific debates.

To answer to the research questions, I reviewed the literature on the theory of ethnicity and the ways of constructing identity of ethnic groups. The theoretical material was a basis for understanding the nature, dynamics, and factors of the ethnic identity construction processes. I revised the past and current debates of the primordialists and the constructivist approaches to the ethnicity, and concluded that the dynamics of ethnic identity shift occurring in the societies all over the world are better explained by the constructivist theories.

The case study of Kazakhstani Russians was analyzed applying the various methods of qualitative research, including surveys, in-depth interviews, content analysis of the publications, and the speeches of political figures and activists. In addition, the methods of participant observation helped in understanding the cultural differentiation of the Russian religious organizations in Kazakhstan.

The revised literature allows us to identify the three multidirectional and mutually incompatible trends in the comprehension of the ethnic identity phenomenon. First, the national elites, irrespective of their forms of government, have always tried to typify ill-assorted fellow citizens/subjects of 
their country, eliminating their ethnic patterns (language, religion, history, etc.) and either replacing them with the characteristics of the dominant ethnic group or creating artificial supranational entities. Second, despite these unifying acts, even the empires for centuries were unable to create a multicultural civic nation and to diminish the role of ethnicity; therefore, it is the most powerful collective identity that can be a source of global conflicts. Third, the ethnic identities are adaptable and changeable, and the different patterns of them could become salient for different reasons and could be changed even without teleological manipulations from outside.

\section{Materials and methods}

The identity shift of ethnic Russians in Kazakhstan is a multifaceted, dynamic process, which needs careful analysis of the demographic data. The most appropriate way to learn about the social composition of the people, their values, opinions, and attitudes is to conduct surveys and opinion polls. The information gathered from the survey can be descriptive, showing the ethnic composition, the age, sex, or other demographic characteristics of the population. Compared to other methods of data collection, the survey can cover the wide range of social groups due to their high representativeness. The statistical and demographic data obtained during the survey could be used for comparative purposes to explain the long-term trends in the society. It can give more accurate and validated outcome with precise results and little subjectivity (Burnham et al 2000).

In order to obtain most up-to-date sociological data on the subject matter, I conducted a survey among ethnic Russians living in different regions of Kazakhstan. The types of the questions were varied, and they were chosen based on the theory of Smith on ethnic identity development (1991). The overall sampling method was based on the generally accepted sampling criteria (Bell 2010) to make it representative in terms of geographical location, age, sex, level of education, occupation, etc. As the target group is ethnic Russians of Kazakhstan, in order to meet the designated criteria, only the citizens of Kazakhstan who self-identify themselves as ethnic Russians were chosen (Creswell 2014).

Overall, 1244 answers were collected during the research between November 2015 and July 2016. The survey was conducted in colleges and universities, as well as in government agencies and commercial companies in Almaty City, Akmola, and Northern Kazakhstan regions. In all, $57.5 \%$ of the respondents were young people between 18 and 25 years, while $15 \%$ of them were between 26 and 35 years and another 15\% were between 36 and 50 years; only $12 \%$ 


\section{Mukhtar Senggirbay \\ Ethnic Identity of Kazakhstani Russians}

were elders with age 51-65 years. A total of 56\% of them were females and $44 \%$ were males. In all, $84.4 \%$ of them were Christians and $12.1 \%$ were from other religions. A total of $68.4 \%$ people had origins in northern Kazakhstan, $10.5 \%$ were from southern Kazakhstan, and $7 \%$ belonged to other regions of Kazakhstan. In all, $62 \%$ of the respondents were well-educated people with the university degrees, 7\% had Masters and PhDs, and the others were undergraduate students at the universities and colleges.

The study also contains two in-depth, focused semi-structured interviews with the political activists of the two different Russian organizations in Kazakhstan. The first interviewee was a 36-year-old ethnic Russian male, the citizen of Kazakhstan living in this country in the third generation. The second informant was a 26-year-old female civic activist of the Russian organization, who currently lives in the city located in southern Kazakhstan. They are the opinion makers and considered to be representing the ethnic Russian community of the country. The analysis of the answers of leading activists could help to learn the current attitude of the Russian community to the issues of nation building.

Another portion of valuable data was obtained from the web pages of the political and religious organizations, as well as the media outlets of Kazakhstani Russians. It includes such websites as russianskz.info and pritvor.kz. The contents of the analytical and op-ed articles, as well as the interviews on political and social issues of these sites, were analyzed using the content analysis method. This helped me to find answers to the research questions on the closeness of the Russian community to the mainstream Kazakh population.

\section{Russian-Kazakh bilingualism}

Kazakhstan has always been the stronghold of the Russian language, where the almost entire population were fluent Russian speakers during the Soviet time. Apart from the Russians and other Slavic nations, Koreans, Germans, and other diasporas were predominantly Russian speakers. The Russian language has always been in a dominant position in most spheres of life, including the government, science, and financial institutions.

However, the Kazakh-Russian bilingualism among ethnic Russian population of Kazakhstan is the new trend in the demographic puzzle of the country. In all, $92.5 \%$ of the respondents in the questionnaire indicated Russian as their mother tongue, while another $2.9 \%$ pointed out both Russian and Kazakh as their first languages, which is surprising since the number of KazakhRussian bilinguals among Russians is traditionally rare in comparison with 
overwhelmingly bilingual ethnic Kazakhs. Moreover, 2.9\% of respondents said that they could speak Kazakh fluently, while 3.7\% of respondents said that they have a good command of it. These findings coincide with the results of the Munday's research conducted in 2009, where 6\% of ethnic Russians claimed to be fluent in Kazakh (Munday 2009). This is a significant advancement, as the number of Russians fluent in Kazakh never exceeded $1 \%$ in Soviet time (Smagulova 2008). In total, almost half of the respondents have the basic understanding of the Kazakh language and could speak with different levels of fluency, while $30 \%$ of them did not know the language at all. In contrast, the 2009 national census indicated that only $25.3 \%$ of ethnic Russians in Kazakhstan had basic knowledge of Kazakh. ${ }^{2}$ Bearing in mind the fact that the majority of the respondents were young people between 18 and 25 years, we can assume that the new generation of Russians is far more inclined to learn the state language from early years. This contrasts with the previous findings of Arenov and Kalmykov, who in 1997 maintained that the state program of expanding the functionality of Kazakh in all spheres of life is failed, as the number of Kazakh-Russian bilinguals among Slavic people has not been increased (Arenov \& Kalmykov 1997). The gradual penetration of the Kazakh language to the traditional Russian-dominated communities inevitably resulted in the increasing number of bilinguals among the nontitular ethnic groups, which was predicted by scientists observing the overall language situation in Kazakhstan after the independence. ${ }^{3}$

In contrast, all the respondents (100\%) can easily communicate in Russian language; the state language program has not affected the pattern. Hence, although the Russian language is shrinking because of the decreasing number of the Russian population, those who decided to stay keep preference in Russian language as their mother tongue. This is a result of the state education reforms, which aimed at kazakhification of the young generation by increasing the number of Kazakh schools, rather than simply eliminating Russian (Pavlenko 2008). For example, the number of preschool organizations in Kazakh had increased from 268 to 328 between 2001 and 2005, while the number of Russian kindergartens had decreased from 444 to 324 . The same trend is visible in the quantity of high schools and the higher education institutions. ${ }^{4}$

2 The results of the 2009 Census in Kazakhstan is analyzed here. Available at http://voprosik.net/ russkij-yazyk-v-kazaxstane-vytesnyat-anglijskim/

3 See, for example, Fierman W. Kazakh language and prospects for its role in Kazakh "groupness". Ab Imperio. 2/2005. Available at http://mason.gmu.edu/ -cenasia/Fierman.pdf

4 See the analysis at http://www.perspektivy.info/rus/rassey/russkiy_yazik_v_kazakhstane.htm 


\section{Mukhtar Senggirbay \\ Ethnic Identity of Kazakhstani Russians}

In addition to bilingualism, the Russian language is experiencing the influence of the Kazakh language and culture. Although some scientists argued that Kazakhstan was one of the centers for the development of the Russian language before, but now the Russian language in Kazakhstan is obtaining more and more characteristics of the local Kazakh language. Apart from the specific words, exclusively used in Kazakhstan, Kazakh has even changed the pronunciation of original Russian words, when $o$ 's are used instead of a's. ${ }^{5}$ Furthermore, Svinchukova concluded that the language consciousness of Kazakhstani Russians is far more different from Russian Russians, where they differently described the meanings of "family", "friend", "land", "husband", "time", and "a man", which indicates the influence of indigenous culture.

Similarly, the leader of the Russian NGO in Kazakhstan in his interview opined that the next generation of Russians would have more patterns of Kazakhs, and the language assimilation is happening now:

I can't say that [Russians are] forgetting their language, culture, etc. as we are at the first stage [of assimilation]. The new generation, who was born after the collapse of the USSR, has different cultural characteristics, slang (the mixture of Kazakh-Russian words) ... the attitude towards Russia is being changed ... Thanks to the Kazakhstani historiography Russia is considered as the country who harmed the Kazakh people ... But this is the first post-soviet generation ... Based on these shifts in the cultural benchmark we can conclude, that the next generations of Russians will be more and more losing the features of the Russian ethnic group.

To conclude, the number of Kazakh-Russian bilinguals has been gradually increasing, changing the ethnic identity of Russians. Ethnic Russians of Kazakhstan are changing from monolingual ethnic group, whose language was dominant in all the spheres of life in the Soviet time, to the bilinguals with different slangs and alien words in their own language. The language consciousness of Russians has also been affected by the Kazakh lifestyle and the worldview. The language assimilation of Russians in Kazakhstan is happening in a natural way as a result of the close integration into the society and shrinking of the number of the Russian population. It is clear that the demographic situation in the country will further facilitate this process.

5 Available at http://www.russkiymir.ru/publications/201160/

6 www.iling-ran.ru/library/sborniki/for_lang/2012_04/11.pdf

7 Author's Interview with the Russian activist living in Northern Kazakhstani city of Kokshetau via Skype. Male, 38 years old, ethnic Russian, and citizen of Kazakhstan (November 2015). 


\section{Level of Kazakhstani Russians' attachment to the Russian homeland culture}

The analysis of the answers to the question on the difference between Kazakhstani Russians and the Russians of Russian Federation shows that the cultural identity of Kazakhstani Russians is generally being shaped by the influence of an Asian Kazakh culture, which is occurring at the level of communities without open induction of the government. Almost all the respondents (91\%) said that Kazakhstani Russians are unequivocally different from kin people living in the neighboring country. Asian family values such as respect for elders, hospitality, close-knit families, and women's respect for their husbands are named as the qualities differing Kazakhstani Russians from those in Russia. In addition, people characterized Kazakhstani Russians as more open-minded, merciful, honest, generous, and intelligent. Nine respondents highlighted the tolerance of local Russians to other ethnic and religious groups, while one person formulated it as "the ability to live in the multiethnic society". Surprisingly, two respondents stated that the Kazakhstani Russians speak pure Russian than those in Russian Federation, and they are more knowledgeable of the Russian culture. On informant wrote, "I feel this attachment [to the Kazakh culture], as I am not Russian anymore, and when travel to my mother country [Russia] they do not consider me as such. With family we observe national Kazakh holidays and revere traditions of the Kazakh people".

Moreover, two respondents stated that the Russians in Russia "are more alcohol consumers", and one said that "Russians in Russia are angry with the life and more resentful".

Interestingly, the Kazakhstani Russians do not represent the pro-homeland attitude in their discourse on the motherland and exhibit different cultural, societal, and psychological markers in comparison with the Russians living in the Russian Federation. Linking back to the Saideman and Ayres's theory of territorialization of ethnicity, I assume that the Kazakhstani Russians have a strong sense of indigenous nationalism, which expresses clear cultural distance from homeland Russians (2008). They maintained that the passiveness of ethnic Russians in protecting their identities is explained by the fact that they have blurred understanding of the Russian homeland nationalism.

\section{Level of integration into the Kazakh society}

The measurement of Kazakhstani Russians' integration with the ethnic Kazakh society was conducted through the open-ended questions regarding their awareness of the Kazakh culture, traditions, and cuisine. In addition, the 


\section{Mukhtar Senggirbay \\ Ethnic Identity of Kazakhstani Russians}

opinion question on the assessment of their attachment to the Kazakh culture was asked during the interviews. The overall analysis of the collected data helps us to make a conclusion that the integration is happening naturally at the level of communities and neighborhood. In all, $68.8 \%$ of the respondents have indicated the marriage traditions of Kazakh people as the factor of their attachment to the culture. One of them said that "they even attended the traditional Kazakh matchmaking ceremony (qudalyq) [as a relative of the bridegroom]". ${ }^{8}$ In all, $42 \%$ of the people named other traditional and religious ceremonies of Kazakhs. Only $12.2 \%$ referred to the official holidays like Nauryz (Kazakh New Year, celebrated in March) and the Kurban Ait (the Muslim holiday of Eid-al-Adha).

Similarly, the food preferences of the Russians are influenced by the Kazakh cuisine. Almost $37.8 \%$ of the respondents maintained that they cook Kazakh national dishes from the horse meat, and one person said that his favorite beverage is kumys (horse milk). Approximately $12.6 \%$ of people did not cook any Kazakh dishes at home.

More interesting findings are on the music preferences of the respondents. Despite the overall influence of the Russian culture, most of ethnic Russians prefer local musicians. To the question "Please, name your 5 most favorite singers (both Russian and Kazakhstani)", 56\% of respondents indicated Kazakh pop music stars, who usually sing in both Kazakh and Russian, while only 28\% named Russian singers from the Russian Federation.

Similarly, the Kazakhstani websites with the local content have more prevalence among the target group of people. The respondents named 41 Kazakhstani and 34 Russian websites as their frequently used information sources on the Internet. The Russian mail and social network service mail.ru is in the top of this list, which was indicated 83 times. In the top five favorite news websites of the respondents, only two were Russian platforms (mail.ru and VKontakte social network), whereas Kazakhstani pro-government news websites nur.kz and zakon.kz, as well as the Tengrinews information agency's website, prevail in the list.

The same picture is in the print and broadcasting media. These findings contrast with the overall opinion that the Kazakhstani Russians are living in the information space of the Russian Federation. Most of the respondents named Russian-language newspapers in Kazakhstan as their favorite media

8 Usually, the matchmakers have to perform traditional rites during the ceremony, which might be challenging for those who are not aware of the Kazakh culture. The matchmaking ceremony is one of the key elements of Kazakh national tradition. As the nation consisted of different tribes, the Kazakh people paid particular attention to this ceremony, which meant establishing diplomatic relations between the tribes. The matchmaking as ritual is practiced nowadays. 
outlets (451 mentions). Only 211 respondents named newspapers of Russian origin. However, the majority of the people (567 people) replied that they do not read any newspapers. The respondents mostly got news from a stateowned Kazakhstani TV channel Khabar TV (431 mentions) and a private Kazakhstani TV channel KTK TV (422 mentions). The Russian RTR (120 mentions) and Channel 1 (118 mentions) were less popular than the local ones. This highlights the dominance of local news channels with the local content, which were interesting for the local residents. In the case of popular Russian TV channels, people watch them mostly for entertainment purposes.

\section{Russian Orthodox Church}

In addition to language, the religion is the most significant part of any ethnic group. The Orthodox Christianity is the crucial part of the Russian ethnic identity. The official Russian Orthodox Church, which enjoys a very close relationship with the Kremlin, has been increasing its influence in Kazakhstan since independence. Estimates say that 6800000 people in Kazakhstan are Orthodox Christians, which makes $44 \%$ of the whole population.' This includes not only ethnic Russians but also other Slavic groups, such as Byelorussians and Ukrainians. Kazakhstan has the largest Orthodox Christian population in CIS countries after Russia, Ukraine, and Belarus. The territory of Kazakhstan is considered the Metropolitan District of the Russian Orthodox Church and directly run from Moscow. The main religious leader of Orthodox Christians in Kazakhstan - the Metropolit of Astana and Almaty - is elected by the Saint Synod of the Russian Orthodox Church, the main decision-making body of the organization, and appointed by the decree of the Patriarch of Moscow and all Russia. ${ }^{10}$ The Metropolitan District of the Russian Orthodox Church in Kazakhstan has been created in 1995 (under a different name). ${ }^{11}$ For now, the Russian Orthodox Church is remaining the most powerful social structure that has a direct influence on the Slavic population of Kazakhstan.

Despite the formal loyalty of the Metropolitan District of the Russian Orthodox Church to the Kazakhstani government, in fact culturally and politically, they show a clear distance from the official state and the overall political and cultural space in Kazakhstan. The official guideline of the

\footnotetext{
9 Available at http://mission-center.com/ru/mission-world/223-world-stat-orthodox

10 The Charter of the Metropolitan District of the Russian Orthodox Church in the Republic of Kazakhstan.

11 The speech of the Saint Patriarch Kirill at the meeting with the community in Kazakhstan. Available at http://www.patriarchia.ru/db/text/1045105.html 


\section{Mukhtar Senggirbay \\ Ethnic Identity of Kazakhstani Russians}

religious organization "the foundations of the social concept of the Russian Orthodox Church" states, "the Church maintains loyalty to the state, but the Divine commandment to save the people in any conditions and any circumstances stands above the loyalty to the government. If the regime compels the Orthodox Church people to retreat from Christ and His Church, and to sinful and pernicious acts, the Church must refuse the obedience". ${ }^{12}$ Most of the religious and cultural gatherings of the Metropolitan District of the Russian Orthodox Church in Kazakhstan have guests from different eparchies in Russia, as well as the official figures or diplomats from Russia. For example, five out of nine panel members of the "Paschal Song" contest, organized in Astana in June 2016, came from Russia. ${ }^{13}$ The official website of the Metropolitan District contains a special column of Kirill, the Patriarch of Moscow and all Russia. ${ }^{14}$ The Church not only legally and organizationally binds the fellow Orthodox believers in Kazakhstan with Russia but also influences their world view drawing a picture of a united Slavic community in the vast Eurasian territory and making them a part of an imagined Slavic world.

The Orthodox Church of Kazakhstan officially shows no clear ethnic preference. The official documents of the Metropolitan District of the Russian Orthodox Church in Kazakhstan have few references to the Russian ethnicity. However, different organizations protecting the rights of ethnic Russians participate in most of the official and cultural gatherings of the Church. Attending the festival of Orthodox Youth "The Spiritual Garden of Semirechiye", organized in July 2016 in Almaty Region of Kazakhstan Sergey Mashkanov, the Executive Secretary of the public organization "The Russian Community of Kazakhstan" said, "This event makes the Russian man a real Russian and a real Orthodox Christian". ${ }^{15}$ Yuriy Zakharov, the Ataman of the Union of Cossacks of Kazakhstan, has led the ceremony of prayer at the big cross procession held on July 12, 2016, in the capital city of the Northern Kazakhstan region - Petropavlovsk. ${ }^{16}$ Orthodox Christianity is the crucial part of Russianness and plays an enormous role in shaping the cultural identity of Russians.

\footnotetext{
12 Available at http://mitropolia.kz/ru/info/of-dokuments/4457-2015-10-02-18-22-13.html

13 Available at http://mitropolia.kz/ru/novosti/sob/5057-fest-03-06-2016.html

14 See the website of the Metropolitan District of the Russian Orthodox Church in Kazakhstan: www. mitropolia.kz

15 Available at http://mitropolia.kz/ru/video/5137-v-sm-14.html

16 Available at http://mitropolia.kz/ru/novosti/eparhia/5134-2016-07-13-05-43-41.html
} 
The Orthodox Church of Kazakhstan declares political neutrality and usually tries to stand aside from the disputes over the ethnicity, language, history, and the geopolitical issues that make cleavage in the Kazakhstani society. However, the analysis of the print materials and the official and non-official websites of the Orthodox Church reveals a clear pro-Russian position of the Orthodox believers and the official Church. The observation of the two biggest churches in Almaty City - The Church of the Christ the Preserver and the Saint Voznesenk Sobor - revealed that there is more integration with the other Orthodox Churches in Russia and the Russian organizations in both Kazakhstan and Russia rather than the Kazakhstani government and civic entities. The information stand at the entrance of the Church of the Christ the Preserver contains the event conducted by the Cossacks with the photos of people in different Cossack warrior uniforms, which are banned in Kazakhstan. The desk at the entrance of the Saint Voznesenk Sobor contains latest information on the events at the Moscow church and the visit of the guests from Russia. There were many visitors on Sunday, almost all of them were speaking in Russian, and the young people below the age of 30 years were almost half of the believers.

The Russian Orthodox Church in Kazakhstan has a clear anti-Kazakh stand in the dispute over the Soviet symbols. One of them is the St. George's orange and black ribbon, which is traditionally used as the symbol of heroism of the Soviet soldiers in the World War II. However, especially after the Russian separatism in the Eastern Ukraine in 2014, where the proRussian rebels used this ribbon as their symbols, the tension over banning it in Kazakhstan is augmented. Some of the Kazakh nationalists consider it as the symbol of occupation of Kazakh lands by the Russian Empire. ${ }^{17}$ Another group of Kazakhs thinks that the St. George's ribbon is the symbol of Russian Orthodox Church missionaries, who used it since the 19th century in contemporary Kazakhstan for the campaign of converting indigenous Muslims to Christians. ${ }^{18}$ On the eve of Victory Day in 2014, the news on outlawing the St. George's ribbons were disseminated by Kazakhstani and Russian media, which was sooner disclaimed by the officials. ${ }^{19}$ However, the unofficial ban was present in most of the public events organized by the

17 Available at http://alashainasy.kz/politic/georgiy-lentasyi-kaydan-shyiktyi-50761/

18 Available at http://elana.kz/\%D0\%B3\%D0\%B5\%D0\%BE\%D1\%80\%D0\%B3\%D0\% B $8 \%$ D $0 \%$ B 9- $\%$ D $0 \%$ B B \% D 0 \% B 5 \% D 0 \% B D \% D 1\% 82 \% D 0 \% B 0 D $1 \% 81 \%$ D $1 \% 8$ B \%D0\%B $4 \%$ D0\%B0\%D2\%A3\%D2\%9B-\%D0\%BB\%D0\%B5\%D0\%BD\%D1\%82\%D0\%B0\%D1\%81\%D1\%8B-\%D0\%B5\%D0\%BC/

19 Available at https://tengrinews.kz/kazakhstan_news/posolstvu-rossii-kazahstane-zapreschali-razdavat-254900/ 


\section{Mukhtar Senggirbay \\ Ethnic Identity of Kazakhstani Russians}

government, and in 2015, the government presented the "Ribbon of Victory", made from the colors of the national flag of Kazakhstan. ${ }^{20}$ Notwithstanding these concerns from the pro-Kazakh groups, the Russian Orthodox Church in Kazakhstan, as well as the Russian organizations, backed the idea of continuing to use the gold and black ribbons. Admitting the fact that the ribbon is the symbol of Russian army later transferred to the Soviet army; the head of the Information Department of the Union of Orthodox Citizens of Kazakhstan suggested "reserving the symbol of heroism and glory to the long period ahead". ${ }^{21}$ Similarly the, Chief Editor of the portal "Russkiye $v$ Kazakbstane" (Russians in Kazakhstan) Ilya Namovir named those who are campaigning against the ribbon as "instigators" and encouraged the fellow citizens to display it at any occasions. ${ }^{22}$

The controversy between Russians and Kazakhs over the symbols is visible from their different transliterations of the geographic names. The Metropolitan District of the Russian Orthodox Church in Kazakhstan in their official documents uses old Soviet transliteration of the geographic names, naming Almaty City as "Alma-Ata" and Shymkent as "Chimkent", whereas the Kazakh community considers the Soviet names of the cities as the symbols of Russian colonization and vehemently react to those who use them in their public speeches. Similarly, the geographic region of Zhetisu (translated from Kazakh as "seven rivers") located in the southeastern part of Kazakhstan, considered as the cradle of Kazakh civilization and the symbol of independent Kazakh statehood, is named by Orthodox Church representatives as "Semirechie" (the Russian translation of Zhetisu), which has opposite historical context, referring to the colonization of the region by the Tsarist regime in the 19th century. The Semirechie Oblast existed between the 1867 and 1898 and was the administrative region of the Russian Empire, which symbolized the further migration of Russians into the Kazakh land, establishing the forts and depriving nomad Kazakhs of their fertile lands. In addition, the TV Studio of the Russian Orthodox Church in Kazakhstan, which "narrates the life of the Russian-speaking population and the Orthodox Church in Kazakhstan", is called "Semirechie". ${ }^{23}$ This is more than just a symbolic war between two ethnic groups. As it was indicated by previous authors, the public histories of Russians and Kazakhs clash in the territory of contemporary Southeastern Kazakhstan (Kolossov 2009). The local Russian movements that existed in

20 Available at http://www.zakon.kz/4709416-lenta-pobedy-pojavilas-v-kazakhstane.html

21 Available at http://spgk.kz/natalya-valujskaya/214-georgievskaya-lenta-simvol-doblesti-i-slavy.html

22 Available at http://www.russianskz.info/society/6630-agitaciya-protiv-georgievskoy-lenty-v-kazahstane-splanirovannaya-provokaciya.html

23 See the official page of the Semirechie TV Studio on VKontakte at https://new.vk.com/club71714467 
the first years of independence pursued aggressive ideas in which the Kazakh identity in the region was perceived as part of the indigenous Russian identity tied with the geographical name of "Semirechie" (Laruelle 2007). Because of the government's purposeful policy, the political movements of ethnic groups were neutralized, but the incompatible public histories of Russian and Kazakh ethnicities were still conspicuous in the country.

\section{Russian influence as a kin-state}

In comparison with other Central Asian countries, Kazakhstan has always been under great political and cultural influence of Russia. The 6,846-kilometer border between Kazakhstan and Russia is considered the longest state border between two countries in the world. The geographical location is not the only factor for the Russian ascendancy. On the eve of independence in 1990, the ethnic Russians outnumbered Kazakhs ( $40 \%$ and 38\%, respectively). Moreover, all other ethnic minorities (with some exception of Uzbeks and Uyghurs in Southern Kazakhstan), as well as the Russified Kazakhs, were Russian speakers, and the nationalist groups in Russia viewed them as part of the great "Russian World". In addition to the demographic dominance of Russian speakers, there was a common understanding that Kazakhstan was a "laboratory of nations", where approximately 130 ethnic groups have been living.

Moreover, most of the biggest cities in contemporary Kazakhstan are considered to be founded in the 18th century as the forts of the Russian Tsardom in Asian periphery. The mass movement of Russians into Kazakh lands was started after the official colonization of three Kazakh khanates by the Russian Empire in the middle of the 18th century. The Russian population of Kazakhstan during the Soviet time enjoyed all the privileges of the indigenous population.

After the collapse of the USSR, both the Russian government and the political elite of the post-Soviet period were not able to determine the boundaries of the Russian nation and could not find an answer to the question of who can be part of the Russian ethnic and national identity. Four out of five definitions of Russian nation provided by Tolz can be applied to the majority of Kazakhstani population regardless of their race and ethnicity: a) union identity (people, whose mission is to create a supranational Russian state); b) nation of all eastern Slavs; c) community of Russian speakers; d) Russians defined racially; and e) civic Russian (rossiyskaya) nation (2011). Thus, the right of the national government of Kazakhstan to create an ethnic nation in 


\section{Mukhtar Senggirbay \\ Ethnic Identity of Kazakhstani Russians}

the whole territory of Kazakhstan was questioned by the Russian intellectuals and politicians.

The concept of "compatriots" (sootechestvenniki), presented by the government of the Russian Federation, which, in fact, could embrace anybody who considers him or her the part of Russian identity, even worsened the situation with determining the border of the Russian nation (Shevel 2011). This ambiguity of the national ideology, as well as the harsh economic and security situation of the Yeltsin era, did not allow Kremlin to properly protect the interests of the Russian population scattered all over the Soviet space.

However, Moscow made a first attempt to legally protect the "compatriots" in 1991 when the parliament of the country adopted a law on citizenship. The law allowed anybody who did not accept the citizenship of other CIS countries to become a citizen of the Russian Federation. Later, in 1994, Russia tried to get legalized a dual citizenship, which could give them more chance to influence the nation-building processes in the independent republics. Nevertheless, the majority of the former USSR members rejected this suggestion.

Ironically, the vagueness of the term of the "Russian nation" and the uncertainty of the boundary gave a freedom for the Russian government to interfere in the internal affairs of CIS countries. From 1994, the Russian establishment started to refer to the Russian speakers in the former Soviet Union as "compatriots". In his 1994 New Year speech, President Yeltsin made a clear statement that the Russian speakers are the inseparable part of the Russian people (Tolz 1998).

In the first ten years of its independence, approximately 4 million ethnic Russians moved to Russia from Kazakhstan. Most of them decided to leave the country for economic and social reasons. In addition, most of them felt abandoned by Russia, who did not pay attention to their problems, including the issues of maintaining national identity. Although there was no direct threat to their language and culture, they were not ready to accept the nationbuilding agenda of the new Kazakhstani government. At the World Congress of Russian Compatriots gathered in 2006 in Saint Petersburg, the head of the delegation from Kazakhstan Lobanov said that the Kazakhstani Russians went through the "15 years of survival solving the problems alone". ${ }^{24}$

The new national policy of Putin on the Russian diaspora was to stop the influx of Russians to the homeland and to take decisive measures to keep the remaining diasporas in their domiciles, apparently in order to use them as

24 The transcript report of the plenary session of the World Congress of Russian Compatriots (October 2006). 
a tool to influence in the national governments. For instance, while visiting the Kazakh capital Astana in 2000, the Russian president Putin asked the Russian diaspora to stay in their current homes and rejected the ideas of some activists to accept the secession of northern regions of Kazakhstan to Russia (Laruelle \& Peyrose 2007).

Soon after becoming president, in October 2001, Vladimir Putin initiated the foundation of the International Council of Russian Compatriots, which held its first congress in 2002. The aim of the council was "the coordination of the activity of public associations of compatriots in order to preserve the ethnic identity and national originality, the spiritual and cultural legacy of the Russian people, spreading of the Russian language and culture in abroad". ${ }^{25}$ This was the clear gesture of the Russian government in protecting and promoting the Russian interests in the world, mostly in the countries with big Russian diasporas.

Since its creation, the World Coordination Council of Russian Compatriots has held five congresses of Russian compatriots with delegates from all over the world. Usually headed by the high-ranking government officials, such as the Minister of Foreign Affairs of Russia Sergey Lavrov and Chairman of the Federal Assembly Sergey Mironov, the congress is very representative and has effective gathering in terms of discussing the issues of Russian diaspora and Russian identity.

The content analysis of the plenary sessions of four congresses of Russians compatriots revealed that the delegates of the meetings are mostly concerned over the ethnic identity of Russians and the cultural integration of "the Russian World" with the Russian Federation. The delegates' most frequently used words were "Russian" (russkiy), "Russia", "compatriots", "Russian language", and "Motherland" (Rodina) (See Table 1). Three out of five delegates representing Kazakhstan at the congress in 2006 complained on the discrimination and oppression of the Russian minority, while two delegates positively assessed the national policy of the Kazakhstani government.

The delegate from Kazakhstan at the session of the Congress of Russian Compatriots in 2006, representative of the "Lad" Slavic Movement Ivan Klimoshenko lamented on the deplorable situation of ethnic Russians in Kazakhstan and read the suggestions of all the Slavic and Russian organizations of Kazakhstan to the government of the Russian Federation. Among other suggestions, he asked Russia to sign an agreement with the government of Kazakhstan on the acknowledgment of the norms of Russian language in

25 See the official website of the International Council of Russian Compatriots at http://www.msrs.ru/ 


\section{Mukhtar Senggirbay \\ Ethnic Identity of Kazakhstani Russians}

Kazakhstan to name the geographical names as they were pronounced before the independence, to regularly conduct seminars for the human rights protecting organizations of the Russian compatriots, and to politically help the Russian compatriots in Central Asian countries to maintain the bilingualism and keep the official status of the Russian language. ${ }^{26}$ The delegates of the congress discussed the suggestions of Klimoshenko and opined that he is raising the very important questions as the Central Asian countries are providing discriminatory policy toward Russians (ibid).

Table 1. The words frequently used in the speeches of the Congress of Russians Compatriots (2006-2015)

\begin{tabular}{|l|c|c|c|c|}
\hline \multirow{2}{*}{ Word/frequency } & \multicolumn{4}{|c|}{ Years } \\
\cline { 2 - 5 } & 2015 & 2012 & 2009 & 2006 \\
\hline Russia & 683 & 718 & 1,014 & 1,143 \\
\hline Compatriot & 606 & 778 & 1,343 & 1,532 \\
\hline Russian & 231 & 240 & 300 & 1,232 \\
\hline Russian language & 78 & 136 & 135 & 377 \\
\hline Unite/unify & 51 & 53 & 65 & 126 \\
\hline Motherland & 56 & 56 & 59 & 84 \\
\hline
\end{tabular}

The protection of the compatriots by the Russian government is becoming more aggressive and militarized. In November 2015, the Minister of the Foreign Affairs of Russia Sergey Lavrov stated that they "will be using all the methods allowed by the international law to aggressively protect the rights of Russian compatriots living in abroad". ${ }^{27}$ In addition, the Russian political and military attacks to the neighboring countries in 2008 (Georgia) and 2014 (Ukraine) were justified as the protection of Russian speakers or Russian "compatriots".

To conclude, the relatively mild protection of interests of compatriots in Kazakhstan by Moscow is explained by a number of factors. First, part of the Russian elite saw the territory of Kazakhstan as an intrinsic part of the Russian identity and considered Russians residing in Kazakhstan as indigenous people living in their own land. Second, the demographic prevalence of Russians in the northern regions of the country did not allow the Kazakhstani government to promote the Kazakhification campaign as successful as in the southern part of the country. Third, because of the number of reasons, before the Putin era, i.e., until 2001, the Russian government and the society did not have a strong

26 The transcript report of the plenary session of the World Congress of Russian Compatriots (October 2006).

27 Available at http://www.bbc.com/russian/news/2015/11/151102_lavrov_russian_world 
sense of homeland nationalism toward their compatriots in Kazakhstan, and it took a long time to mobilize the political elite and the society around the nationalistic slogans. Fourth, the Russian population of Kazakhstan had a little attachment to Russia as a homeland, as most of them had predominantly Soviet identities.

\section{Discussion}

The research revealed the significant changes in the identity patterns of ethnic Russians in Kazakhstan, which resulted from the process of consolidation of the vigorous state-protected ethnic Kazakh identity. Losing the previous dominant position in demography, the Russians bowed to the inevitable Kazakhification of the society. The change in the language preferences shows that the new generation of Russians is gradually accepting the new trend Kazakh-Russian bilingualism - which is being promoted and implemented by the government of Kazakhstan and by the overwhelmingly ethnocratic Kazakh political elite. The Kazakh-Russian bilingualism is partly an outcome of the state language policy of spreading Kazakh, but at the same time, Russians learn Kazakh as their second language and Russian is not going to lose its prioritized role as a mother tongue.

This research found out that the new local identity of Kazakhstani Russian is being shaped with some degree of cultural distance from the Russians of the Russian Federation. The solidifying identity of the "Kazakhstani Russian" is distinguished by its specific lexicon with the words and expressions from Kazakh language incomprehensible to the Russians living outside Kazakhstan. In addition, the "Kazakh Russian" has more signs of the Kazakh people, especially in their attitude to the family values. They have different food preferences, which adopted the patterns of Kazakh cuisine. Despite the overall assumption, the Kazakhstani Russians have less commitment to the contemporary Russian culture in the Russian Federation, as they maintain the local Kazakhstani cultural agenda, which does not necessarily coincide with the trends in Russia. This is visible from the music preferences of the respondents, as well as from their general attitude to Moscow. Similarly, this research challenged the established idea that the Russians in Kazakhstan are living in the information space of Russia, because they mostly read and watch the local media.

Another finding of this research is that it singled out the main factors facilitating the identity shift of the Russian community of Kazakhstan. The identity of Russians is being shaped, edited, and adapted to the local environment, thanks to the close integration with Kazakhs. Thus, the 


\section{Mukhtar Senggirbay \\ Ethnic Identity of Kazakhstani Russians}

traditional Kazakh ceremonies and rites, marriage, and other family events have greater influence. As the traditional family gatherings are a significant part of the Kazakh cultural life, the Russians attending the ceremonies experience close cultural integration with Kazakhs.

Although the Russians accepted the central role of the Kazakh ethnic identity in the nation-building processes, they are interested in keeping the status quo, and they mostly see the current Kazakhstani state as some modified form of the Soviet Union with the Kazakhs obtaining the role of "brother nation", which was the prerogative of Russians in the USSR. Therefore, the majority of Kazakhstani Russians perceive themselves not as the newcomers but as an indigenous community living in their own land.

I substantiated that currently the Orthodox Church is the most powerful institution in preserving and protecting the identity of Russians in Kazakhstan. The Kazakhstani Orthodox Church is under the great influence of the Russian Church and is considered to play the central role in determining and promoting the Russianness. In addition, I argued that in comparison with other state and non-state actors, the Orthodox Church of Kazakhstan has a clear pro-Russian position in identity construction and nation-building processes. In addition, they have more anti-Kazakh stand in the symbolic wars between the Kazakh nationalist groups and more cosmopolitan supporters of the civic nation.

For a period of 10-15 years after the collapse of the Soviet Union, the Russian Federation was reluctant to put the Russian question in Kazakhstan in its political agenda. This is explained by the fact that at least northern territories of Kazakhstan were mostly considered as part of the Russian space, which meant that there was no immediate threat to the identity of Russians residing in this area. However, the Putin era is characterized by the gradual nationalizing domestic and foreign policies, which coincided with more aggressive nation-building processes in Kazakhstan. But still Moscow has a little role in preserving the ethnic identity of Kazakhstani Russians. However, under the Brubaker's "triadic nexus" formula, the Kazakhstani government is constrained from advancing an active ethnic nation-building agenda, although the more aggressive and more overwhelming Kazakh community has been demanding it from the Kazakh political establishment.

From the theory, we have learned that language, religion, culture, cuisine, and music are the main components of ethnic identity. Furthermore, in the literature review, we have discussed that the commonality or difference of some of these elements does not necessarily provoke or prevent conflicts. 
Similarly, the commonality of language, religion, and culture did not bind the Russians to the mainstream popular culture in the Russian Federation.

The contribution of this analysis to the theory of ethnicity is that it validated the constructivist theory of ethnic identity, showing the track of identity markers of Russians, being shaped within the period of a quarter century. The slow but constant solidification of "Kazakhified" Russian identity proves the Allahar's conclusion that each generation is the modified version of the previous one.

\section{Acknowledgment}

I would like to thank the Institute for Conflict, Transition, and Peace Research of the Aberdeen University for their generous scholarship that allowed me to work on this project. I express my gratitude to my supervisor at the University of Aberdeen Dr John Nagle for his advice and expertise. Moreover, I thank the Central Eurasian Studies Society (CESS) for their travel grant that helped me to present this paper at the annual conference in Seattle in 2017, where Dr Diana Kudaibergenova made valuable comments.

\section{References}

Allahar, A. L. 2001. “The Politics of Ethnic Identity Construction”, Identity, vol. 1, no. 3, pp. 197-208.

Anderson, A. B. 2001. "The Complexity of Ethnic Identities: A Postmodern Reevaluation”, Identity, vol. 1, no. 3, pp. 209-223.

Arenov, M. \& Kalmykov, S. 1997. “The Present Language Situation in Kazakhstan”, Russian Social Science Review, vol. 38, no. 3, pp. 56-64.

Barrington, L. W., Herron, E.S. \& Silver, B.D. 2003. "The Motherland Is Calling: Views of Homeland among Russians in the near Abroad”, World Politics, vol. 55, no. 2, pp. 290-313.

Bayar, M. 2009. "Reconsidering primordialism: an alternative approach to the study of ethnicity”, Ethnic and Racial Studies, vol. 32, no. 9, pp. 1639-1657.

Bell, J. 2010. Doing your research project, 5th ed. edn, Open University Press, GB.

Brubaker, R. 2004. Ethnicity without Groups.

Brubaker, R. 1996. Ethnic and Racial Studies, vol. 19, pp. 411.

Brubaker, R. 2005. “The 'diaspora' diaspora”, Ethnic and Racial Studies, vol. 28, no. 1, pp. $1-19$.

Calhoun, C. 1993. "Nationalism and Ethnicity", Annual Review of Sociology, vol. 19, pp. 211239.

Cederman, L., Girardin, L. \& Gleditsch, K.S. 2009. "Ethnonationalist Triads: Assessing the Influence of Kin Groups on Civil Wars”, World Politics, vol. 61, no. 3, pp. 403-437.

Chandra, K. (ed) 2012. Constructivist Theories of Ethnic Politics, Oxford University Press. 


\section{Mukhtar Senggirbay \\ Ethnic Identity of Kazakhstani Russians}

Creswell, J. 2014. Research design: qualitative, quantitative, and mixed methods approaches, 4th edn,.

Cummings, S. N. 2006. "Legitimation and Identification in Kazakhstan", Nationalism and Ethnic Politics, vol. 12, no. 2, pp. 177-204.

Dadabayeva, G. \& Adibayeva, A. 2010. "Post-Soviet Kazakhstan: Nationalism and Language Issues", The Soviet and Post-Soviet Review, vol. 37, pp. 125-141.

Eriksen, T. H. 1991. "Ethnicity versus Nationalism”, Journal of Peace Research, vol. 28, no. 3, pp. 263-278.

Fearon, J. D. \& Laitin, D. D. 2000. "Violence and the Social Construction of Ethnic Identity”, International Organization, vol. 54, no. 4, pp. 845-877.

Fierman, W. 2006. "Language and Education in Post-Soviet Kazakhstan: Kazakh Medium Instruction in Urban Schools", Russian Review, vol. 65, no. 1, pp. 98.

Gat, A. \& Yakobson, A. 2012. Nations, The Long History and Deep Roots of Political Ethnicity and Nationalism, Cambridge University Press, Cambridge.

Hale, H. 2008, The Foundations of Ethnic Politics: Separatism of States and Nations in Eurasia and the World.

Horowitz, D. 2000, Ethnic groups in conflict, 2nd edn, University of California Press, Berkeley, CA.

Howard, N. 2011, Kazakh and Russian Identities in Transition: the Case of Kazakhstan, University of St. Andrews.

Isaacs, R. and Polese, A. 2015. "Between 'imagined' and 'real' nation-building: identities and nationhood in post-Soviet Central Asia”. Nationalities Papers, vol. 43(3), pp.371-382.

Jha, M. 2003, "Ethnicity and Nation Building in Post-Soviet Kazakhstan", Himalayan and Central Asian Studies, vol. 7, no. 2, pp. 25-0_4.

Kadyrzhanov, R. 2014, Etnokul'turnyi Simvolizm i Natsional'naia Identichnost' Kazakhstana, The Institute of Philosophy, Political and Religious Studies, Almaty, Kazakhstan.

Kolossov, V. 2009, "After Empire: Identities and Territorialities in the Post-Soviet Space" in $A$ Companion to Political Geography, eds. J. Agnew, K. Mitchell \& G. Toal, Blackwell Publishing,, pp. 251-270.

Kolstø, P. \& Blakkisrud, H. (eds) 2016, The New Russian Nationalism: Imperialism, Ethnicity and Authoritarianism (2000-15), Edinburgh University Press.

Kramarenko, M. 2014, 04/11-last update, Komu vygodno antievraziistvo? [Who benefits from ani-Eurasianism?]. Available: http://spgk.kz/analiticheskoe-obozrenie/444-komu-vygodnoantievrazijstvo.html [2016, 07/16].

Kroneberg, C. \& Wimmer, A. 2012, "Struggling over the Boundaries of Belonging: A Formal Model of Nation Building, Ethnic Closure, and Populism”, American Journal of Sociology, vol. 118, no. 1, pp. 176-230.

Laruelle, M. \& Peyrouse, S. 2007, “Russkiy vopros” v nezavisimom Kazakhstane: istoriya, politika, identichnost', Natalis, Moscow.

Laruelle, M. 2014, “The Three Discursive Paradigms of State Identity in Kazakhstan. Kazakhness, Kazakhstannes and Transnationalism" in Nationalism and Identity Construc- 


\section{Journal of Nationalism, Memory \& Language Politics 13(1)}

tion in Central Asia. Dimensions, Dynamics and Directions, ed. M. Omelicheva, Lexington Books,, pp. 1-20.

Laruelle, M. 2015, "In Search of Kazakhness: the Televisual Landscape and Screening of Nation in Kazakhstan" in Demokratizatsiya: The Journal of Post-Soviet Democratization, vol. 23 (3), pp. 321-340

Lee, C. 2004, "Languages and Ethnic Politics in Central Asia: the Case of Kazakhstan”, Journal of International and Area Studies, vol. 11, no. 1, pp. 101-116.

Mun, O. 2014, Re-imagining national identity through early literacy textbooks in Kazakhstan, Lehigh University.

Munday, E. 2009, Language and Identification in Contemporary Kazakhstan, The University of Edinburgh.

Nagle, J. 2013, "Does Having a Kin State Lessen the Likelihood of Minorities Engaging in Secessionist Mobilization?: An Analysis of the Moderating Influence of Kin States", $\mathrm{Na}$ tionalism and Ethnic Politics, vol. 19, no. 3, pp. 287-309.

Oka, N. 2007, Managing Ethnicity Under Authoritarian Rule: Transborder Nationalisms in Post-Soviet Kazakhstan, Institute of Developing Economies, JIBA, Chiba, Japan.

Olcott, M.B. 2002, Kazakhstan: unfulfilled promise, Carnegie Endowment for International Peace, Washington.

Pavlenko, A. 2008, "Russian in Post-Soviet Countries”, Russian Linguistics, vol. 32, no. 1, pp. 59-80.

Peyrouse, S. 2007, "Nationhood and the minority question in Central Asia. The Russians in Kazakhstan”, Europe-Asia Studies, vol. 59, no. 3, pp. 481-501.

Poppe, E. \& Hagendoorn, L. 2003, “Titular Identification of Russians in Former Soviet Republics”, Europe-Asia Studies, vol. 55, no. 5, pp. 771-787.

Saideman, S. \& Ayres, R.W. 2008, For Kin or Country: Xenophobia, Nationalism, and War.

Schatz, E. 2000, "The Politics of Multiple Identities: Lineage and Ethnicity in Kazakhstan”, Europe-Asia Studies, vol. 52, no. 3, pp. 489-506.

Smith, A.D. 2002, "When is a Nation", Geopolitics, vol. 7, no. 2, pp. 5-32.

Smith, A.D. 1987, The ethnic origins of nations, Blackwell.

Smith, A.D. 1996, "Culture, Community and Territory: The Politics of Ethnicity and Nationalism”, International Affairs (Royal Institute of International Affairs 1944-), vol. 72, no. 3, pp. 445-458.

Smith, G. \& Wilson, A. 1997, “Rethinking Russia’s Post-Soviet Diaspora: The Potential for Political Mobilisation in Eastern Ukraine and North-East Estonia", Europe-Asia Studies, vol. 49, no. 5, pp. 845-864.

Spehr, S. \& Kassenova, N. 2012, "Kazakhstan: constructing identity in a post-Soviet society”, Asian Ethnicity, vol. 13, no. 2, pp. 135-151.

Suny, R.G. 1999, "Provisional Stabilities: The Politics of Identities in Post-Soviet Eurasia”, International Security, vol. 24, no. 3, pp. 139-178.

Tishkov, V. 1994, Nationalities and Conflicting Ethnicity in Post-Communist Russia, UNRISD Discussion Papers. 
Mukhtar Senggirbay

Ethnic Identity of Kazakhstani Russians

Valuyskaya, N. 2015, 05/17-last update, Interview with Kaskelen Episcope Gennadiy (Gogolev) [Homepage of The Union of Orthdox Christian Citizens of Kazakhstan], [Online]. Available:http://spgk.kz/natalya-valujskaya/610-beseda-s-episkopom-kaskelenskim-gennadiem-gogolevym-upravlyayushchim-delami-mitropolichego-okruga-rektorom-almatinskoj-dukhovnoj-seminarii-i-predsedatelem-soyuza-pravoslavnykh-grazhdan-spg-kazakhstana-konstantinom-byalynitskim-birulya.html [2016, 07/17].

Wolff, S. 2006, Ethnic Conflict: A Global Perspective, Oxford University Press, Oxford. 